\title{
Short-term effects of thermal stress on the responses of branchial protein quality control and osmoregulation in a reef-associated fish, Chromis viridis
}

\author{
Cheng-Hao Tang ${ }^{1,2^{*}}$, Ming-Yih Leu ${ }^{2,3}$, Katrina Shao ${ }^{4}$, Lie-Yueh Hwang ${ }^{5}$ and Wen-Been Chang ${ }^{2,3}$
}

\begin{abstract}
Background: Changes in ambient temperature seriously affect physiological regulation and biochemical reactions in ectotherms. However, transient elevation in oceanic temperature occurs naturally during the day. Short-term elevation in the ambient temperature affects different physiological responses in marine fish, including cellular protein stability and osmotic balance of the internal environment. Since fish gills are vital osmoregulatory organ which directly contacts external environment, activation of cytoprotective responses to maintain gill cell viability and biological function is essential for fish survival under challenging environmental conditions. The purpose of this study was to investigate the short-term effects of elevated temperature on physiological regulation in the gills of a marine teleost, blue green damselfish (Chromis viridis).
\end{abstract}

Results: As part of the stress response, plasma glucose levels were induced by short-term hyperthermic exposure (12 h). Furthermore, upregulation of the levels of gill heat shock proteins (HSPs) and ubiquitinated proteins was essential for preventing the accumulation of protein aggregations in branchial cells of $C$. viridis under hyperthermic stress. The specific activity of branchial $\mathrm{Na}^{+} / \mathrm{K}^{+}$-ATPase (NKA), however, significantly reduced while the amount of protein was similar between normal and high-temperature groups.

Conclusions: The present study provided the evidence to illustrate that activation of the branchial protein quality control mechanism to carry out cytoprotective response was involved in coping with thermal stress. However, plasma osmolality and muscle water content, respectively, that slightly but evidently increased and decreased might result from impaired osmoregulatory ability due to hyperthermia-decreased gill NKA activity.

Keywords: Thermal stress; Blue-green damselfish; Protein quality control; Osmoregulation

\section{Background}

Most organisms on Earth are ectotherms which have to survive and adapt to temperature fluctuations (Hochachka and Somero 2002; Guschina and Harwood 2006; Somero 2010). Temperature fundamentally affects all aspects of physiology by influencing the reactive rates as well as the physical properties of biological molecules (Hochachka and Somero 2002; Crockett and Londraville 2006). For marine ectotherms including fish, environmental temperature has

\footnotetext{
* Correspondence: wtang@mail.ndhu.edu.tw

'Institute of Marine Biotechnology, National Dong Hwa University, 2 Houwan Road, Checheng, Pingtung 944, Taiwan

${ }^{2}$ National Museum of Marine Biology and Aquarium, Pingtung 944, Taiwan

Full list of author information is available at the end of the article
}

the pervasive effects on physiological and biochemical functions at all levels of biological organization, from molecule to organism (Jobling 1995; Hochachka and Somero 2002; Hofmann et al. 2002; Donaldson et al. 2008). According to the tolerance range of temperature, the fishes can be classified into two groups, eurythermal and stenothermal species. Eurythermal fish can maintain metabolic activity at temperatures as low as Antarctic fish can survive and withstand temperature as high as the avian and mammalian body temperature. In contrast, changes in environmental temperature may lead to the poor maintenance of physiological homeostasis in stenothermal 
species, resulting in temperature stress (Hochachka and Somero 2002; Somero 2010; Long et al. 2012).

Under adverse conditions, the physiological stress responses of organisms should be promptly activated to correct the disturbance, and cytoprotective mechanisms should be employed for the maintenance of cell viability and functional activity; otherwise, the survival of stressed organism will be in danger (Hofmann and Somero 1995, 1996; Hofmann et al. 2002; Kregel 2002; Cui et al. 2013). Furthermore, cellular proteins indeed carry out various physiological functions responsible for cell viability. The expression and maintenance of protein quality depends on mechanisms beyond those involved in transcription and translation (Wickner et al. 1999). Chaperones and proteases mediating the mechanism of protein quality control (PQC) to prevent the accumulation of aggregated proteins and maintain cellular function and activity are highly conserved in organisms from different taxa (Gottesman et al. 1997; Wickner et al. 1999; Goldberg 2003; Bukau et al. 2006). Therefore, PQC should be a critical cytoprotective mechanism for coping with temperature stress in ectotherms. However, study on the responses of PQC mechanism to temperature challenge in fish is limited. The fish gills are the multifunctional organ which directly contacts the external environment (Evans et al. 2005; Kaneko et al. 2008); therefore, it is an excellent model to study stress responses and environmental effects in vivo.

Environmental temperature significantly influences internal electrolyte and osmotic homeostasis in aquatic ectotherms (Christensen 1975; Amoudi et al. 1996; Metz et al. 2003; Sardella et al. 2004, 2008a). It is due to active ion-transporting mechanisms that are regulated by many proteins, while the cellular proteins of stenothermal species are only marginally stable at a limited range of temperature (Hochachka and Somero 2002; Metz et al. 2003; Crockett and Londraville 2006; Sardella et al. 2008a). The fundamental transporter proteins responsible for osmoregulation in gill epithelia have been reported in previous studies (see Hirose et al. 2003; Evans et al. 2005; Hwang and Lee 2007; Kaneko et al. 2008; Hwang et al. 2011). Among them, $\mathrm{Na}^{+} / \mathrm{K}^{+}$-ATPase (NKA) is the most important enzyme that actively transports $\mathrm{Na}^{+}$out of and $\mathrm{K}^{+}$into animal cells for sustaining intracellular homeostasis as well as for providing the driving force for ion-transporting systems in fish gills (Hwang and Lee 2007; Hwang et al. 2011). Therefore, branchial NKA responses (mRNA and protein expression and specific activity) have been used to assess the osmoregulatory status/ability of teleosts (Epstein et al. 1967; Hwang and Lee 2007; Kaneko et al. 2008). In this regard, it is worth examining the branchial NKA responses to investigate the impact of temperature stress on osmoregulatory responses in stenothermal teleosts and clarify whether the protein expression or specific activity of gill NKA is susceptible to temperature challenge.
The blue-green damselfish (Chromis viridis) is a stenothermal teleost that is abundant on coral reefs throughout much of the Indo-Pacific region (Allen 1991; Lieske and Myers 1994), including southern Taiwan (Shen et al. 1993). Previous studies have shown that the average temperature in Nanwan Bay, Kenting National Park, southern Taiwan is $26^{\circ} \mathrm{C}$ to $27^{\circ} \mathrm{C}$ and increases to approximately $32^{\circ} \mathrm{C}$ to $33^{\circ} \mathrm{C}$ during the day (Meng et al. 2008; Mayfield et al. 2013). Accordingly, the normal and hyperthermic temperatures of $26^{\circ} \mathrm{C}$ and $32^{\circ} \mathrm{C}$, respectively, were used in this study. The goal of this study was to investigate the stress responses, PQC mechanism, and osmoregulatory response in the gills of $C$. viridis exposed to an increase in ambient temperature $\left(32^{\circ} \mathrm{C}\right)$ for $12 \mathrm{~h}$ to ascertain the physiological strategies employed by stenothermal teleosts under short-term thermal stress.

\section{Methods}

\section{Experimental animals and environments}

Blue-green damselfish $2.8 \pm 0.4 \mathrm{~g}$ in weight and $4.1 \pm$ $0.7 \mathrm{~cm}$ in length were obtained from husbandry center of National Museum of Marine Biology and Aquarium (NMMBA), Pingtung, Taiwan. Fish were reared in a tank with a $300 \mathrm{~L}$ seawater (SW, 33\% to 35\%) circulating system at $26 \pm 0.5^{\circ} \mathrm{C}$ with a daily 12 -h photoperiod at least 4 weeks for the holding period. The waters were continuously circulated through fabric-floss filters, and the environmental salinity was measured by the refractomter PAL-06S (ATAGO, Tokyo, Japan). Fish were fed daily with commercial pellets (TetraMarin', Tetra, Melle, Germany) except $48 \mathrm{~h}$ prior to the sampling. No mortality was observed during the holding period. For all following experiments, 28 individuals were sacrificed. The facilities and protocols for the experimental fish were approved by the Institutional Animal Care and Use Committee of College of Marine Sciences, Nation Dong Hwa University (i.e., NMMBA).

\section{Short-term exposure of blue-green damselfish to elevated temperature}

After the holding period, blue-green damselfish were randomly divided into two different groups for the control and hyperthermic treatment. The temperature was maintained at $26^{\circ} \mathrm{C} \pm 0.5^{\circ} \mathrm{C}$ for control group and $32^{\circ} \mathrm{C} \pm 0.5^{\circ} \mathrm{C}$ for hyperthermic group. A $100 \mathrm{~W}$ automatic heater (EBOJÄGER, El Segundo, CA, USA) was used to maintain the temperature. After 12-h short-term exposure, the experimental animals were randomly selected from two tanks and anesthetized by immersion in MS-222 (50 mg/l) before sampling.

\section{Analysis of plasma glucose levels, plasma osmolality, and muscle water content}

Fish blood was collected from the heart using heparinized $1 \mathrm{ml}$ syringes and $21 \mathrm{G}$ needles. After centrifugation 
at $1,000 \times g$ at $4^{\circ} \mathrm{C}$ for $10 \mathrm{~min}$, the plasma osmolality and glucose levels were measured immediately using a Wescor 5520 Vapro osmometer (Logan, Utah, USA) and an ACCU-CHEK Go blood glucose meter (Roche, Mannheim, Germany), respectively. The muscle water content (MWC) was measured gravimetrically after drying at $100^{\circ} \mathrm{C}$ for $48 \mathrm{~h}$. The procedures of analysis of plasma glucose levels, plasma osmolality, and MWC were determined according to Tang and Lee (2013b).

\section{Antibodies}

The primary antibodies used in the present study included (1) anti-heat shock protein 90 (HSP90) (1:1,500 dilution), a rabbit polyclonal antibody (\#4874; Cell Signaling Technology, Beverly, MA, USA) corresponding to human HSP90; (2) anti-HSP70 (1:2500 dilution), a mouse monoclonal antibody (H 5147; Sigma, St. Louis, MO, USA) generated by immunization with purified bovine brain HSP70; (3) antiHSP60 (1:1,000 dilution), a mouse monoclonal antibody (H3524; Sigma) recognizes an epitope located between amino acid residues 383-419 of the human; (4) antiubiquitin (1:2,000 dilution), a rabbit polyclonal antibody (\#3933; Cell Signaling Technology) corresponding to the $\mathrm{N}$-terminus of the human ubiquitin protein that detects ubiquitin, polyubiquitin, and ubiquitinated proteins; (5) anti- $\beta$-actin (1:5,000 dilution), a monoclonal antibody (ab8226, Abcam, Cambridge, England, UK) against residues 1-100 of human $\beta$-actin; and (6) anti-NKA (1:4,000 dilution), a mouse monoclonal antibody ( $\alpha 5$; Developmental Studies Hybridoma Bank, Iowa City, IA, USA) raised against the $\alpha$-subunit of avian NKA. The secondary antibodies for Western blot analyses were horseradish peroxidase (HRP)-conjugated goat anti-rabbit or anti-mouse IgG (Chemicon, Temecula, CA, USA). A 1:12,000 dilution of secondary antibodies was used in the present study.

\section{Cell protein fractionation and isolation of aggregated proteins}

The procedures of cell protein fractionation and isolation of aggregated proteins were performed according to published studies (Aufricht et al. 1998; Chen et al. 2002; Rinehart et al. 2006; Tang and Lee 2013a). The studied tissues were homogenized in chilled extraction buffer containing $0.1 \%$ Triton X-100, $60 \mathrm{mM}$ PIPES, $1 \mathrm{mM}$ EDTA, $1 \mathrm{mM}$ ethylene glyco-bis(aminoethyl ether)-N,N,N,N-tetraacetic acid and $100 \mathrm{mM} \mathrm{NaCl}$. In addition, $40 \mu \mathrm{l}$ of a proteinase inhibitor cocktail (Roche, Mannheim, Germany) was added for each milliliter of chilled extraction buffer. Homogenization was performed in $2 \mathrm{ml}$ tubes with a Polytron PT1200E (Lucerne, Switzerland) at appropriate speed for $10 \mathrm{~s}$. The homogenate was centrifuged at $680 \times g$ for $10 \mathrm{~min}$ at $4{ }^{\circ} \mathrm{C}$ to pellet nuclei and large cellular fragments. The supernatant was assigned to the total cell lysates for the following analyses of HSPs and ubiquitinated proteins. The resulting supernatant (total cell lysate) was centrifuged at $35,000 \times g$ for $14 \mathrm{~min}$ at $4^{\circ} \mathrm{C}$ to separate the Triton-soluble and insoluble protein fractions. Aggregated proteins were isolated by differential centrifugation. The Triton-insoluble fraction was resuspended twice in extraction buffer, sonicated, and pelleted at $17,000 \times g$ for $30 \mathrm{~min}$ at $4{ }^{\circ} \mathrm{C}$. The resultant pellet was again resuspended in extraction buffer, sonicated, and pelleted at $5,000 \times g$ for $30 \mathrm{~min}$ at $4^{\circ} \mathrm{C}$. The pellet consisting of aggregated proteins was resuspended in extraction buffer (aggregated protein fraction) and stored at $-80^{\circ} \mathrm{C}$. Protein concentrations of total cell lysates and aggregated protein fractions were determined with a BCA Protein Assay Kit (Pierce, Hercules, CA, USA) using bovine serum albumin (BSA, Pierce) as a standard.

\section{Preparation of crude membrane fractions}

The procedure of preparation of crude gill membrane fractions was performed according to Tang et al. (2012). The gills of the fish were excised and blotted dry immediately after the fish were killed by spinal pithing. The samples were immersed in liquid nitrogen and placed into ice-cold homogenization buffer (250 mM sucrose, $1 \mathrm{mM}$ EDTA, $30 \mathrm{mM}$ Tris, $\mathrm{pH}$ 7.4). Homogenization was performed in $2 \mathrm{ml}$ tubes using the Polytron PT1200E homogenizer (Lucerne, Switzerland) at appropriate speed for $10 \mathrm{~s}$. Debris, nuclei, and lysosomes were removed by low-speed centrifugation $\left(12,000 \times g\right.$ for $\left.10 \mathrm{~min}, 4^{\circ} \mathrm{C}\right)$. The remaining supernatant was centrifuged at medium speed $(20,800 \times g$ for $1 \mathrm{~h}, 4^{\circ} \mathrm{C}$ ). The resulting pellet was resuspended in homogenization buffer and stored at $-80^{\circ} \mathrm{C}$. The pelleted fraction contained large fragments of the plasma membrane along with membranes from the Golgi and the endoplasmic reticulum, but no small cytoplasmic vesicles as they typically do not pellet down unless greater forces $(100,000 \times g$ for $>1 \mathrm{~h}$ ) are applied (Alberts et al. 1994). This fraction is therefore referred to as the crude membrane fraction. Aliquots of crude cell membrane fractions were saved for protein determination analysis. Protein concentrations were determined with BCA Protein Assay Kit (Pierce) using bovine serum albumin (Pierce) as a standard. The crude membrane fractions were stored at $-80^{\circ} \mathrm{C}$ until the analysis of Western blot and specific activity of gill NKA.

\section{Western blot analysis}

Gill proteins were heated in sample buffer at $90^{\circ} \mathrm{C}$ for $10 \mathrm{~min}$ for detection of HSPs in total cell lysates or at $37^{\circ} \mathrm{C}$ for $30 \mathrm{~min}$ for detection of NKA in crude membrane fractions. The samples were separated by electrophoresis on sodium dodecyl sulfate (SDS) containing $8 \%$ polyacrylamide gels for detection of HSPs and NKA. The prestained protein molecular weight marker was purchased from Fermentas (SM0671; Hanover, MD, USA). The separated proteins were 
Table 1 Effects of short-term exposure to high temperature on physiological parameters of blue-green damselfish

\begin{tabular}{lll}
\hline Environments & NT & HT \\
\hline Plasma glucose levels (mg/dL) & $54.0 \pm 2.6$ & $100.2 \pm 8.2^{*}$ \\
Plasma osmolality (mOsm/kg) & $347.1 \pm 4.9$ & $379.2 \pm 6.7^{*}$ \\
Muscle water content (\%) & $87.4 \pm 0.8$ & $79.5 \pm 0.6^{*}$
\end{tabular}

Values are expressed as the mean \pm SEM, $n=6$ for all groups. NT, normal temperature $\left(26^{\circ} \mathrm{C} \pm 0.5^{\circ} \mathrm{C}\right) ; \mathrm{HT}$, high temperature $\left(32^{\circ} \mathrm{C} \pm 0.5^{\circ} \mathrm{C}\right)$. The asterisk indicated a significant difference $(P<0.05)$ by unpaired $t$ test.

then transferred to PVDF membranes $(0.45 \mu \mathrm{m}$ pore size $)$ (Millipore, Bedford, MA, USA) by electroblotting. After preincubation for $3 \mathrm{~h}$ in phosphate-buffered saline (PBS) $\left(137 \mathrm{mM} \mathrm{NaCl}, 3 \mathrm{mM} \mathrm{KCl}, 10 \mathrm{mM} \mathrm{Na} \mathrm{HPO}_{4}, 2 \mathrm{mM}\right.$ $\left.\mathrm{KH}_{2} \mathrm{PO}_{4}\right)$ with $0.075 \%(v / v)$ Tween 20, pH 7.4 (PBST) buffer containing $5 \%(w / v)$ nonfat dried milk to minimize nonspecific binding, the blots were incubated at room temperature for $3 \mathrm{~h}$ with primary antibody diluted in 1\% BSA and 0.05\% sodium azide in PBST, washed in PBST, and incubated at room temperature for $2 \mathrm{~h}$ with secondary antibody. The immunoreactive bands were developed with HRP substrate, Western Blot Enhancer Kit (T-Pro, New Taipei City, Taiwan), and imaged with a Fusion FX7 system (Vilbert Lourmat, Eberhardzell, Germany). $\beta$-actin was used as the loading control for HSPs. To verify even the loading of the crude membrane fractions, the protein amount of each lane on the blots was quantified after staining the membranes with Ponceau S (Romero-Calvo et al. 2010). The developed blots were imported as TIFF files. Immunoreactions were analyzed using a software package (MCID software, Imaging Research, Ontario, Canada). The results were converted to numerical values to compare the relative protein abundance of the immunoreactions.

\section{Dot blot analysis}

Levels of ubiquitinated proteins in the gills were measured using an immunochemical analysis modified from the study of Todgham et al. (2007). Equal amounts of total protein $(10 \mu \mathrm{g})$ from each sample were blotted onto pre-wetted nitrocellulose membrane $(0.2 \mu \mathrm{m}$ pore size) (Sartorius, Epsom, Surrey, UK) in triplicates by gravity filtration using a BioDot dot blotter (Bio-Rad, Hercules, CA, USA). Wells were washed twice with $200 \mu \mathrm{l}$ of PBST and then heat-fixed at $65^{\circ} \mathrm{C}$ for $20 \mathrm{~min}$. Then, the membrane was blocked in $5 \%(w / v)$ nonfat dried milk in PBST for $1.5 \mathrm{~h}$. Following blocking, the membranes were washed three times in PBST (for $5 \mathrm{~min}$ each). The membranes were incubated at room temperature for $3 \mathrm{~h}$ with primary antibody (anti-ubiquitin antibody, Cell Signaling Technology) diluted in 1\% BSA and $0.05 \%$ sodium azide in PBST, washed in PBST, and subsequently incubated at room temperature for $2 \mathrm{~h}$ with secondary antibody. The immunoreaction was developed with Immobilon Western Chemiluminescent HRP Substrate (Millipore) and imaged with a Fusion FX7 system (Vilbert
Lourmat, Eberhardzell, Germany). The developed membranes were imported as TIFF files. The immunoreactive signals were analyzed using a software package (MCID software). The results were converted to numerical values to compare the levels of ubiquitinated proteins of the immunoreactive signals.

\section{Specific $\mathrm{Na}^{+} / \mathrm{K}^{+}$-ATPase activity}

A method using 96-well microplate to measure the inorganic phosphate concentrations for determination of NKA activity was performed according to Tang et al. (2010) with minor modification. Aliquots of the suspension of gill crude membrane fractions, prepared as described above, were used to determine the protein concentration and NKA enzyme activity. The reaction medium (final concentration, $100 \mathrm{mM}$ imidazole- $\mathrm{HCl}$ buffer, $\mathrm{pH}$ 7.6, $125 \mathrm{mM} \mathrm{NaCl}$, $75 \mathrm{mM} \mathrm{KCl}, 7.5 \mathrm{mM} \mathrm{MgCl} 2$ ) was prepared according to Tang et al. (2010). Then, $10 \mu \mathrm{l}$ crude membrane fractions, $50 \mu 10 \mathrm{mM}$ ouabain (specific inhibitor of NKA) or deionized water, and $100 \mu \mathrm{l} 10 \mathrm{mM} \mathrm{Na} \mathrm{NaTP}_{2}$ were added to $340 \mu \mathrm{l}$ of the reaction medium. The enzyme activity was defined as the difference between the inorganic phosphate liberated in the presence and absence of ouabain in the reaction mixture. The reaction mixture was incubated at the exposure temperatures for $20 \mathrm{~min}$ followed by immediate ice bath for $10 \mathrm{~min}$ to stop the reaction (Cheng et al. 1999). Because the previous studies have demonstrated that the specific NKA activity which was measured at the exposed temperature of fish would correlate with the level of in vivo activity (Metz et al. 2003; Sardella et al., 2008a), therefore, the reaction was run at the exposure temperatures in this study. The concentration of inorganic phosphate was measured according to Doulgerakia et al. (2002). The colorimetric reagent consisted of $1 \%$ Tween-20 and $0.75 \%$ ammonium molybdate in $0.9 \mathrm{M} \mathrm{H}_{2} \mathrm{SO}_{4}$. The reaction mixtures and colorimetric reagent were mixed in a 1:1 $(v / v)$ ratio, and then, the concentration of inorganic phosphate in each samples was determined by a microplate reader (VERSAmax, Molecular Devices, Sunnyvale, CA, USA) at $405 \mathrm{~nm}$. Each sample was determined in triplicates. Some protocols determine the concentration of inorganic phosphate by measuring the color of molybdenum blue, which is the reduced product of phosphomolybdate. The instability of color formation and reagents, however, were variables in those protocols. The formation of the unreduced phosphomolybdate in the present study is directly proportional to the amounts of inorganic phosphate.

\section{Statistical analysis}

In all experiments, statistical significance was determined using Student's $t$ test $(P<0.05)$ for group data analysis. Values were expressed as means \pm S.E.M. 


\section{Results}

Physiological parameters: plasma glucose, osmolality, and muscle water content

Compared to the normal temperature $\left(\mathrm{NT}, 26^{\circ} \mathrm{C}\right)$ group, the levels of plasma glucose of blue-green damselfish were significantly elevated after exposure to high temperature $\left(\mathrm{HT}, 32^{\circ} \mathrm{C}\right)$ condition. In addition, plasma osmolality and MWC which significantly increased and decreased, respectively, were found when blue-green damselfish were exposed to elevated temperature (Table 1).

\section{Changes of the abundance of gill heat shock proteins and} ubiquitin-conjugated proteins

In the cellular stress responses, the relative protein abundance of stress proteins (i.e., HSPs) in fish gills was examined. Immunoblotting of the gills (Figure 1) from NT- and
A

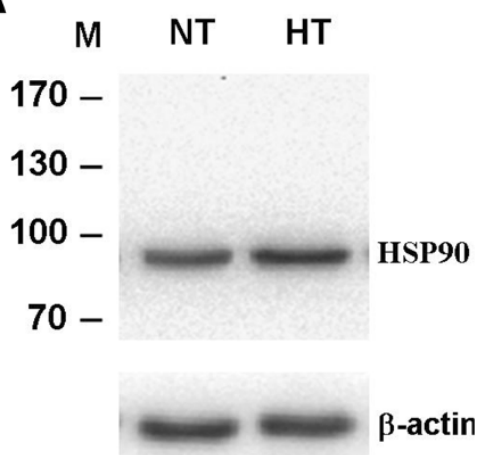

C

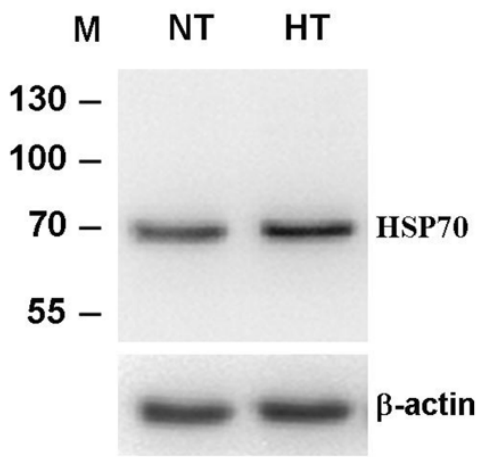

E

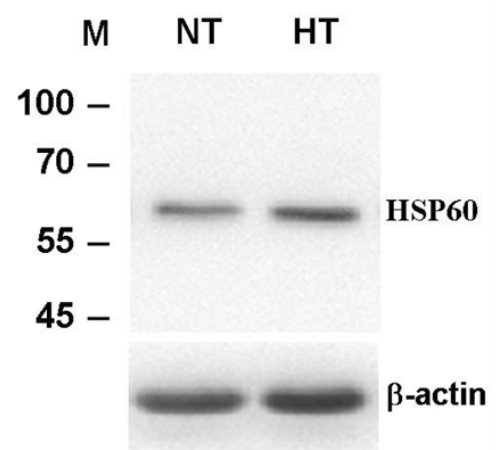

B

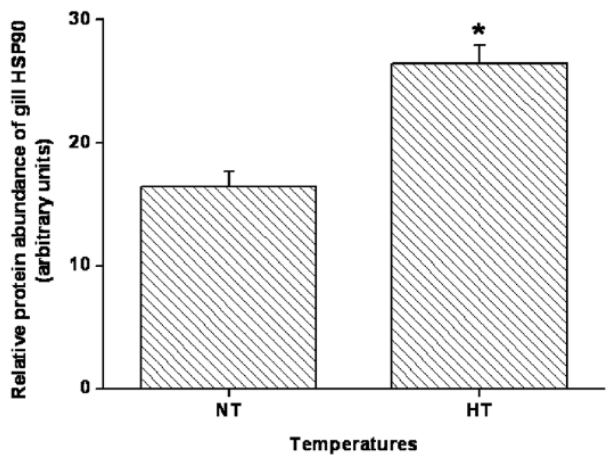

D

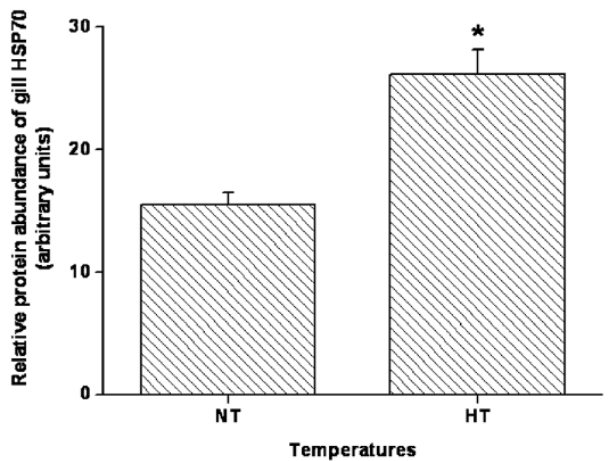

$\mathbf{F}$

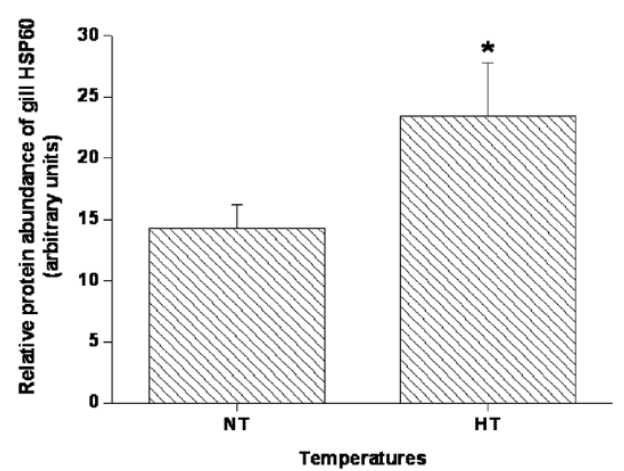

Figure 1 Protein expression of branchial heat shock protein 90 (HSP90), HSP70, and HSP60 in blue-green damselfish (Chromis viridis). The representative immunoblots of HSP90, HSP70, and HSP60 showed a single immunoreactive band with a molecular mass about 90 (A), 70 (C), and $60 \mathrm{kDa}(\mathbf{E})$, respectively. The immunoreactive bands of HT group are more intensive than that in the NT group. The protein amounts of HSP90 (B), HSP70 (D), and HSP60 (F) increased evidently after hyperthermic exposure $(n=5)$. $\beta$-actin was used as the loading control. The asterisk indicated a significant difference $(P<0.05)$ by unpaired $t$ test. Values were mean \pm SEM. $M$, marker; NT, normal temperature $\left(26^{\circ} \mathrm{C}\right) ; H T$, high temperature $\left(32^{\circ} \mathrm{C}\right)$. 
HT-exposed blue-green damselfish probed with primary antibodies to HSP90 (Figure 1A,B), HSP70 (Figure 1C,D), and HSP60 (Figure 1E,F) resulted in single immunoreactive bands with molecular weights of approximately 90 (Figure 1A), 70 (Figure 1C), and $60 \mathrm{kDa}$ (Figure 1E), respectively. Protein expression levels of branchial HSPs in HT-exposed fish were significantly higher than those in NT-exposed fish (1.61-fold for HSP90, Figure 1B; 1.69-fold for HSP70, Figure 1D; and 1.64-fold for HSP60, Figure 1F). The response of ubiquitin-conjugated proteins in bluegreen damselfish gills to reduced salinity was assayed by using dot-blot analysis. Dot-blot analysis showed the levels of ubiquitin-conjugated proteins in the gills of HT-exposed C. viridis were higher than those in NT-exposed C. viridis (Figure 2). Importantly, the aggregated proteins were maintained at similar levels between HT- $(48.4 \pm 10.5 \mu \mathrm{g} / \mathrm{mg}$ total protein) and NT-exposed fish $(40.1 \pm 7.8 \mu \mathrm{g} / \mathrm{mg}$ total protein) (Figure 3).

\section{$\mathrm{Na}^{+} / \mathrm{K}^{+}$-ATPase responses}

The relative protein abundance of branchial NKA was examined. Immunoblotting of the gills from NT- and HT-exposed blue-green damselfish obtained a single immunoreactive band with molecular weight of approximately $105 \mathrm{kDa}$ (Figure 4A). The protein abundance of gill NKA $\alpha$-subunit in $C$. viridis was similar between two studied environmental temperatures (Figure 4B). However, reduction of gill NKA specific activities was found in fish exposed to HT condition (Figure 4C).

\section{Discussion}

Organisms naturally experience diverse environmental challenges throughout their lives. For marine ectothermic organisms, ambient temperature is one of the most significant factors that affects diverse regulation (Hochachka and Somero 2002; Hofmann et al. 2002; Crockett and Londraville 2006; Donaldson et al. 2008; Somero 2010). In fish physiological responses, the mechanisms associated with stress and osmoregulatory responses are susceptible to variation of environmental temperature (Hofmann and Somero 1995; Iwama et al. 1999; Gonzalez and McDonald 2000; Metz et al. 2003; Place et al. 2004; Sardella et al. 2004; Fiess et al. 2007; Sardella et al. 2008a,b; Cui et al. 2011; Deane and Woo 2011; Feidantsis et al. 2012; Cui et al. 2013). For ecological relevance, the experimental temperatures used in this study were based on the average $\left(26^{\circ} \mathrm{C}\right)$ and daytime $\left(32^{\circ} \mathrm{C}\right)$ temperatures in Nanwan Bay, southern Taiwan (Meng et al. 2008; Mayfield et al. 2013) because C. viridis is abundant in Nanwan Bay (Shen et al. 1993).

The stress responses are energy demanding processes, changes in plasma glucose concentrations have widely been used as a stress bioindicator at the organismal level, because glucose is the main fuel source in animals

\section{A Ub-conjugated proteins}

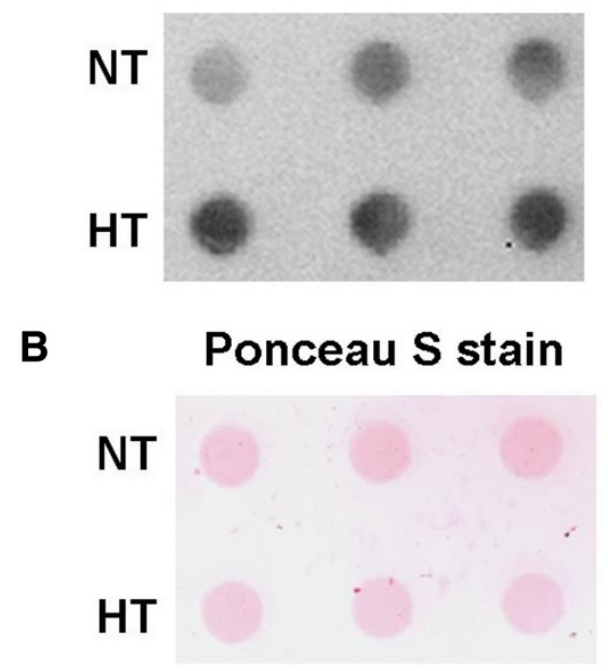

C

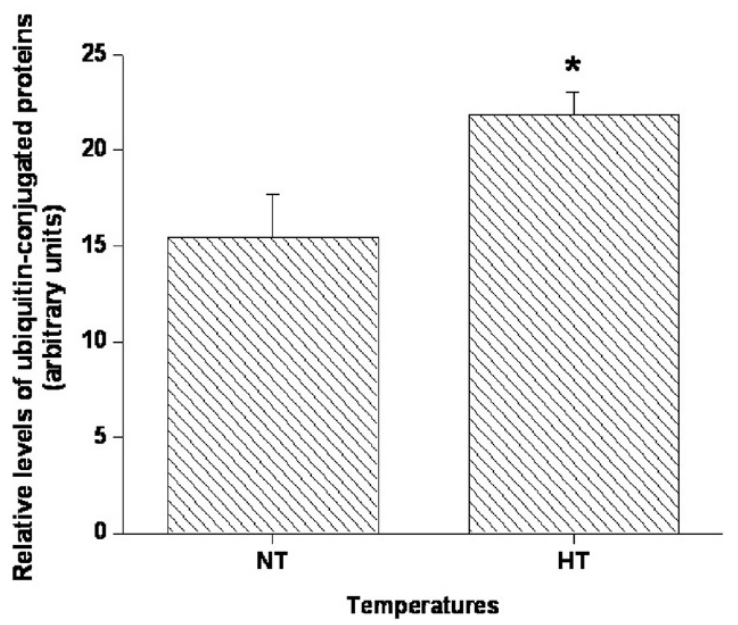

Figure 2 Dot-blot analysis of the levels of ubiquitin-conjugated proteins in the gills of blue-green damselfish (Chromis viridis). (A) Ubiquitin-conjugated protein levels were shown as relative values based on dot intensities. (B) Ponceau $\mathbf{S}$ total protein stain of blots was used as loading control. (C) Significant elevation of the levels of ubiquitin-conjugated proteins was found after hyperthermic exposure. Unpaired $t$ test was used for the statistics. Values are means \pm S.E.M $(n=5)$. NT, normal temperature $\left(26^{\circ} \mathrm{C}\right)$; HT, high temperature $\left(32^{\circ} \mathrm{C}\right)$.

(Basu et al. 2001; Afonso et al. 2003; Iwama et al. 2006). To evaluate whether a short-term increase in environmental temperature would thermally stress $C$. viridis, its plasma glucose concentrations were measured. Plasma glucose levels increased from $54.0 \pm 2.6$ to $100.2 \pm 8.2 \mathrm{mg} / \mathrm{dL}$ after hyperthermic exposure (Table 1). Similar patterns were found in juvenile Chinook salmon (Oncorhynchus tshawytscha) (Mesa et al. 2002) and two Antarctic nototheniid fish, Pagothenia borchgrevinki and Trematomus bernacchii 


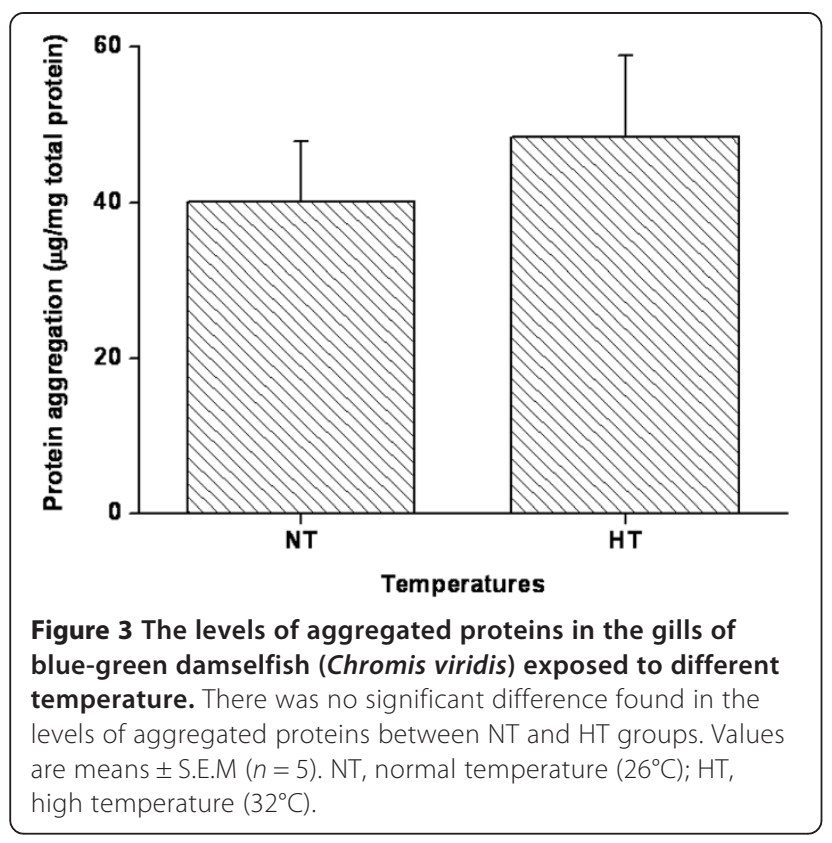

(Lowe and Davison 2005), after short-term exposure to thermal stress. Therefore, $32^{\circ} \mathrm{C}$ should be a stressful temperature for $C$. viridis and more energy is needed to compensate for the cost of the energy-demanding processes involved in coping with thermal stress.

At the cellular level, temperature stress affects protein synthesis and conformation, causing protein damage (Hofmann and Somero 1995, 1996; Hochachka and Somero 2002; Rinehart et al. 2006; Todgham et al. 2007). Once the damaged protein exists, the regulation associated with the repair and degradation of damaged proteins is subsequently triggered to prevent increase in protein aggregation that is harmful to cell viability (Kabakov and Gabai 1993; Wickner et al. 1999; Goldberg 2003; Bukau et al. 2006). Activation of HSPs and protein ubiquitination which are involved in protein refolding and degradation in response to change in ambient temperature in aquatic animals have been reported in several previous studies (Hofmann and Somero 1995, 1996; Hochachka and Somero 2002; Hofmann et al. 2002; Place et al. 2004; Iwama et al. 2006; Todgham et al. 2007; Cui et al. 2011, 2013). However, the evidence of protein aggregation level was lack to address the PQC mechanism adequately. In the present study, HSPs and ubiquitinconjugated proteins evidently elevated in $C$. viridis exposed to $32^{\circ} \mathrm{C}$ (Figures 1 and 2), whereas protein aggregation was similar to the normal temperature group at low level (Figure 3). However, elevated protein aggregation levels were found when organisms were cultured in high mortality conditions (Rinehart et al. 2006; Choe and Strange 2008). Thus, our findings assumed that the upregulation of HSPs and ubiquitin-conjugated proteins was sufficient to prevent the accumulation of aggregated proteins in $C$. viridis to adapt to transient
A

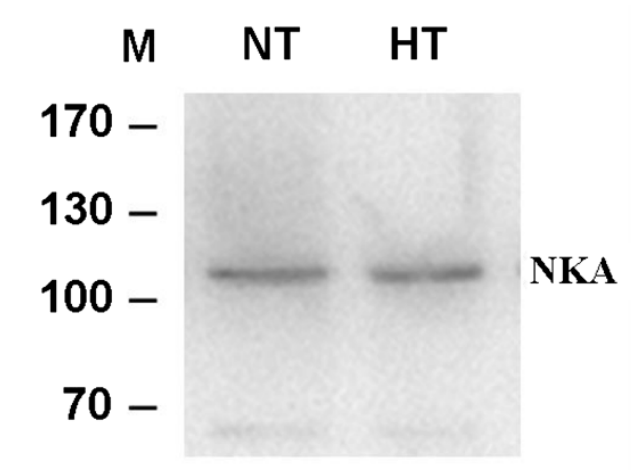

B
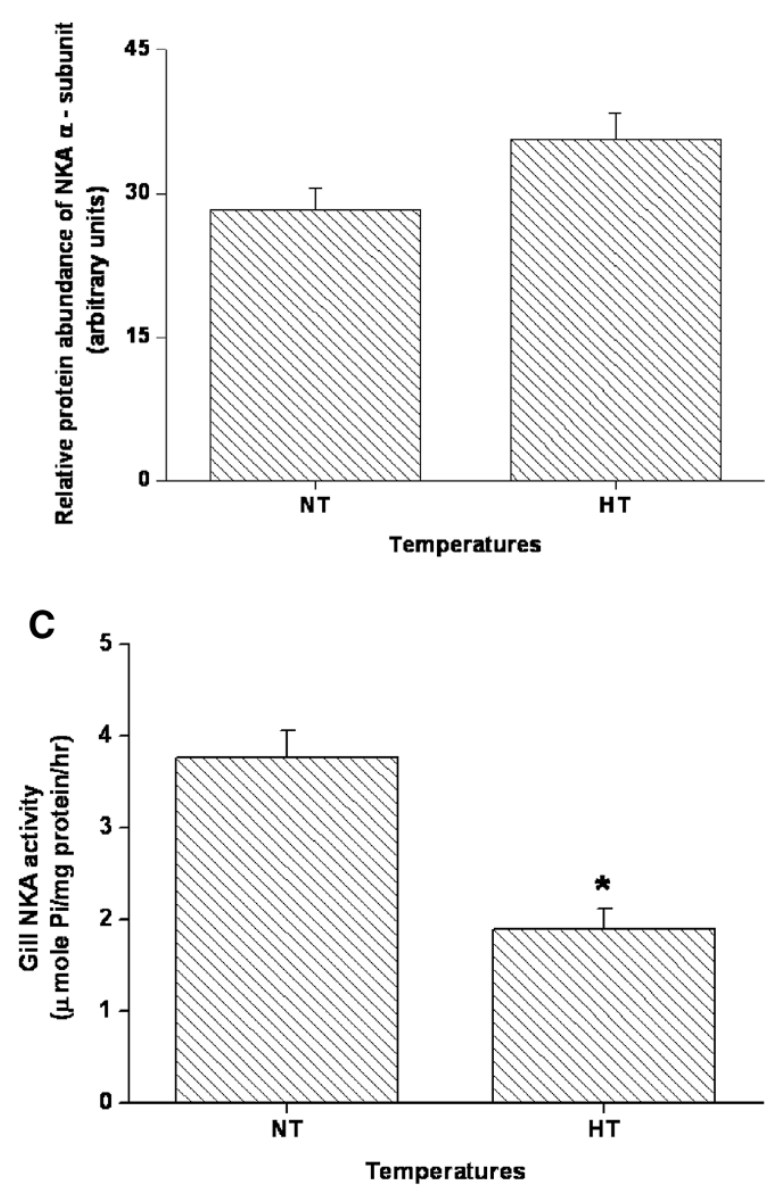

Figure 4 Impact of changes in temperature on the responses of gill $\mathrm{Na}^{+} / \mathrm{K}^{+}$-ATPase (NKA) in blue-green damselfish (Chromis viridis). (A) Immunoblots of $C$. viridis gills probed with a monoclonal antibody (a5; DSHB) to NKA a-subunit. The immunoreactive bands of HT group were more intensive than NT group. (B) Relative abundance of immunoreactive bands of NKA a-subunit in the gills of different temperature groups $(n=5)$. Expression of NKA a-subunit was similar between NT and HT groups. (C) Specific activity of gill NKA in C. viridis in response to elevation of ambient temperature $(n=5)$. Downregulation of branchial NKA activity was found after hyperthermic exposure. The asterisk indicated a significant difference $(P<0.05)$ by unpaired $t$ test. Values were mean \pm SEM. M, marker; NT, normal temperature $\left(26^{\circ} \mathrm{C}\right) ; \mathrm{HT}$, high temperature $\left(32^{\circ} \mathrm{C}\right)$. 
elevation of ambient temperature. To our knowledge, this is the first study to examine the expression of HSPs, ubiquitinated proteins, and protein aggregation levels simultaneously in fish, in response to temperature challenge.

The internal ionic and osmotic balance of fish is affected by ambient temperature (Gonzalez and McDonald 2000; Metz et al. 2003; Sardella et al. 2004; Fiess et al. 2007; Sardella et al. 2008a, b). After exposure of C. viridis to hyperthermic condition, significant increase of plasma osmolality as well as decrease of muscle water content were found (Table 1). This might be explained by the marked depression of branchial NKA activity at $32^{\circ} \mathrm{C}$, even though the protein expression of gill NKA was not affected (Figure 4). Moreover, in this study, NKA activity was assayed at the exposure temperature of the fish to show the apparent NKA activity to provide a physiological interpretation of our results. This is because temperature affects the reactivity of molecules by affecting protein conformation, kinetic properties, and assembly. On the other hand, activation of ion transporter system is energy-required while the rate of cellular respiration the main process for energy providing is temperature-dependent (Hochachka and Somero 2002). Therefore, the decrease in gill NKA activity reflected that metabolically-dependent ion transporter proteins are more susceptible to temperature change than is passive ion diffusion (Christensen 1975; Hochachka and Somero 2002). Furthermore, temperature inhibited the specific activity of NKA was found in the common carp (Cyprinus carpio) and the Mozambique tilapia (Oreochromis mossambicus). By using biochemical and immunohistochemical approaches, it was found that a lower apparent NKA activity was compensated for by strongly enhanced NKA expression (Metz et al. 2003; Sardella et al. 2008a). The present study was difficult to rule out the possibility that the other compensatory responses were enhanced in C. viridis only based on protein expression of gill NKA.

\section{Conclusions}

A local species and recorded in situ water temperature were used in this study to understand the impacts of short-term increases in temperature on stress responses, cellular protein stability, and osmoregulatory status in a reef-associated fish by using physiological and molecular approaches. The results provided the implication for elucidation that $C$. viridis possesses the molecular mechanisms for coping with thermal stress to maintain protein stability, but inhibitory effects on osmoregulatory ability resulted in slight changes of plasma osmolality and muscle water content.

\section{Competing interests}

The authors declare that they have no competing interests.

\section{Authors' contributions}

The work presented here was carried out in collaboration among all authors. $\mathrm{CHT}, \mathrm{MYL}$, and KS designed and carried out the experiments. CHT drafted the manuscript. $\mathrm{LYH}$ and WBC helped for rearing the experimental animals. All authors made comments on the manuscript. All authors read and approved the final manuscript.

\section{Acknowledgements}

The a5 monoclonal antibody were purchased from the Developmental Studies Hybridoma Bank (DSHB) maintained by the Department of Pharmacology and Molecular Sciences, John Hopkins University School of Medicine, Baltimore, MD 2120521205, and the Department of Biological Sciences, University of lowa, lowa City, IA 52242, under Contract N01-HD-6-2915, NICHD, USA. This study was supported by the grants from the National Science Council of Taiwan (NSC 102-2313-B-259-001 to C.H.T.) and the National Museum of Marine Biology and Aquarium (to C.H.T.)

\section{Author details}

${ }^{1}$ Institute of Marine Biotechnology, National Dong Hwa University, 2 Houwan Road, Checheng, Pingtung 944, Taiwan. ${ }^{2}$ National Museum of Marine Biology and Aquarium, Pingtung 944, Taiwan. ${ }^{3}$ Institute of Marine Biodiversity and Evolutionary Biology, National Dong Hwa University, Pingtung 944, Taiwan. ${ }^{4}$ Department of Ecology, Evolution, and Marine Biology, University of California, Santa Barbara, CA 93106-9610, USA. ${ }^{5}$ Taishi Station, Mariculture Research Center, Fisheries Research Institute, Council of Agriculture, Taishi, Yulin 636, Taiwan.

Received: 24 February 2014 Accepted: 3 April 2014

Published online: 29 April 2014

\section{References}

Afonso L, Basu N, Nakano K, Devlin R, Iwama G (2003) Sex-related differences in the organismal and cellular stress response in juvenile salmon exposed to treated bleached kraft mill effluent. Fish Physiol Biochem 29:173-179

Alberts B, Bray D, Lewis J, Raff M, Roberts K, Watson JD (1994) Molecular biology of the cell, 3rd edn. Garland Science, New York

Allen GR (1991) Damselfishes of the world. Mergus, Germany

Amoudi MA, El-Sayed A-FM, El-Ghobashy A (1996) Effects of thermal and thermohaline shocks on survival and osmotic concentration of the tilapias Oreochromis mossambicus and Oreochromis aureus $\times$ Oreochromis niloticus hybrids. J World Aquacult Soc 27:456-461

Aufricht C, Lu E, Thulin G, Kashgarian M, Siegel NJ, Van Why SK (1998) ATP releases HSP-72 from protein aggregates after renal ischemia. Am J Physiol-Renal Physiol 274:F268-F274

Basu N, Kennedy C, Hodson P, Iwama G (2001) Altered stress responses in rainbow trout following a dietary administration of cortisol and $\beta$-napthoflavone. Fish Physiol Biochem 25:131-140

Bukau B, Weissman J, Horwich A (2006) Molecular chaperones and protein quality control. Cell 125:443-451

Chen Q, Ma E, Behar KL, Xu T, Haddad GG (2002) Role of trehalose phosphate synthase in anoxia tolerance and development in Drosophila melanogaster. J Biol Chem 277:3274-3279

Cheng SXJ, Aizman O, Nairn AC, Greengard P, Aperia A (1999) [Ca2+]i determines the effects of protein kinases $\mathrm{A}$ and $\mathrm{C}$ on activity of rat renal $\mathrm{Na}+\mathrm{K}+-\mathrm{ATPase}$. J Physiol 518:37-46

Choe KP, Strange K (2008) Genome-wide RNAi screen and in vivo protein aggregation reporters identify degradation of damaged proteins as an essential hypertonic stress response. Am J Physiol Cell Physiol 295:C1488-C1498

Christensen HN (1975) Biological transport. W. A. Benjamin, Inc., Reading, MA Crockett EL, Londraville RL (2006) Temperature. In: Evans DH, Claiborne JB (eds) The physiology of fishes, 3rd edn. CRC Press, Boca Raton, FL, pp 231-269

Cui M, Zhang QZ, Yao ZJ, Zhang ZH (2011) Molecular cloning and expression analysis of heat-shock protein 70 in orange-spotted grouper Epinephelus coioides following heat shock and Vibrio alginolyticus challenge. J Fish Biol 79:486-501

Cui Y, Liu B, Xie J, Xu P, Tsion HMH, Zhang Y (2013) The effect of hyperthermia on cell viability, oxidative damage, and heat shock protein expression in hepatic cells of grass carp (Ctenopharyngodon idellus). J Therm Biol 38:355-361

Deane EE, Woo NYS (2011) Advances and perspectives on the regulation and expression of piscine heat shock proteins. Rev Fish Biol Fish 21:153-185 
Donaldson MR, Cooke SJ, Patterson DA, Macdonald JS (2008) Cold shock and fish. J Fish Biol 73:1491-1530

Doulgerakia A, Papadopoulou-Daifoti Z, Tsakiris S (2002) Effects of L-phenylalanine on acetylcholinesterase and $\mathrm{Na}^{+}, \mathrm{K}^{+}$-ATPase activities in suckling rat frontal cortex, hippocampus and hypothalamus. Z Naturforsch [C] 57:182-188

Epstein FH, Katz Al, Pickford GE (1967) Sodium- and potassium-activated adenosine triphosphatase of gills: role in adaptation of teleosts to salt water. Science 156 (3779):1245-1247

Evans DH, Piermarini PM, Choe KP (2005) The multifunctional fish gill: dominant site of gas exchange, osmoregulation, acid-base regulation, and excretion of nitrogenous waste. Physiol Rev 85:97-177

Feidantsis K, Pörtner HO, Markou T, Lazou A, Michaelidis B (2012) Involvement of p38 MAPK in the induction of Hsp70 during acute thermal stress in red blood cells of the gilthead sea bream, Sparus aurata. J Exp Zool Part A 317:303-310

Fiess JC, Kunkel-Patterson A, Mathias L, Riley LG, Yancey PH, Hirano T, Grau EG (2007) Effects of environmental salinity and temperature on osmoregulatory ability, organic osmolytes, and plasma hormone profiles in the Mozambique tilapia (Oreochromis mossambicus). Comp Biochem Physiol A-Mol Integr Physiol 146:252-264

Goldberg AL (2003) Protein degradation and protection against misfolded or damaged proteins. Nature 426(6968):895-899

Gonzalez RJ, McDonald DG (2000) lonoregulatory responses to temperature change in two species of freshwater fish. Fish Physiol Biochem 22:311-317

Gottesman S, Wickner S, Maurizi MR (1997) Protein quality control: triage by chaperones and proteases. Genes Dev 11:815-823

Guschina IA, Harwood JL (2006) Mechanisms of temperature adaptation in poikilotherms. FEBS Lett 580:5477-5483

Hirose S, Kaneko T, Naito N, Takei Y (2003) Molecular biology of major components of chloride cells. Comp Biochem Phys B-Biochem Mol Biol 136:593-620

Hochachka PW, Somero GN (2002) Biochemical adaptation: mechanism and process in physiological evolution, vol 480. Oxford University Press, New York

Hofmann G, Somero G (1995) Evidence for protein damage at environmental temperatures: seasonal changes in levels of ubiquitin conjugates and hsp70 in the intertidal mussel Mytilus trossulus. J Exp Biol 198:1509-1518

Hofmann GE, Somero GN (1996) Interspecific variation in thermal denaturation of proteins in the congeneric mussels Mytilus trossulus and M. galloprovincialis: evidence from the heat-shock response and protein ubiquitination. Mar Biol 126:65-75

Hofmann GE, Buckley BA, Place SP, Zippay ML (2002) Molecular chaperones in ectothermic marine animals: biochemical function and gene expression. Integr Comp Biol 42:808-814

Hwang PP, Lee TH (2007) New insights into fish ion regulation and mitochondrion-rich cells. Comp Biochem Physiol A-Mol Integr Physio 148:479-497

Hwang PP, Lee TH, Lin LY (2011) lon regulation in fish gills: recent progress in the cellular and molecular mechanisms. Am J Physiol-Regul Integr Comp Physiol 301:R28-R47

Iwama GK, Vijayan MM, Forsyth RB (1999) Heat shock proteins and physiological stress in fish. Am Zool 39:901-909

Iwama GK, Afonso LOB, Vijayan MM (2006) Stress in fishes. In: Evans DH, Claiborne JB (eds) The physiology of fishes. CRC Press, Boca Raton, FL, pp 319-335

Kabakov AE, Gabai VL (1993) Protein aggregation as primary and characteristic cell reaction to various stresses. Experientia 49:706-713

Kaneko T, Watanabe S, Lee KM (2008) Functional morphology of mitochondrion-rich cells in euryhaline and stenohaline teleosts. Terrapub, Tokyo

Kregel KC (2002) Heat shock proteins: modifying factors in physiological stress responses and acquired thermotolerance. J Appl Physiol 92:2177-2186

Lieske E, Myers RF (1994) Coral reef fishes: Indo-Pacific and Caribbean. HarperCollins, London

Long Y, Li L, Li Q, He X, Cui Z (2012) Transcriptomic characterization of temperature stress responses in larval zebrafish. PLoS ONE 7:e37209

Lowe CJ, Davison W (2005) Plasma osmolarity, glucose concentration and erythrocyte responses of two Antarctic nototheniid fishes to acute and chronic thermal change. J Fish Biol 67:752-766

Jobling (1995) Environmental biology of fishes. Chapman and Hall Publishers, London, $455 \mathrm{pp}$

Mayfield AB, Chen MN, Meng PJ, Lin HJ, Chen CS, Liu PJ (2013) The physiological response of the reef coral Pocillopora damicornis to elevated temperature: results from coral reef mesocosm experiments in Southern Taiwan. Mar Environ Res 86:1-11

Meng PJ, Lee HJ, Wang JT, Chen CC, Lin HJ, Tew KS, Hsieh WJ (2008) A longterm survey on anthropogenic impacts to the water quality of coral reefs, southern Taiwan. Environ Pollut 156:67-75

Mesa MG, Weiland L, Wagner P (2002) Effects of acute thermal stress on the survival, predator avoidance, and physiology of juvenile fall chinook salmon. Northwest Sci 76:118-128

Metz JR, van den Burg EH, Bonga SE, Flik G (2003) Regulation of branchial $\mathrm{Na}^{+} / \mathrm{K}^{+}$-ATPase in common carp Cyprinus carpio L. acclimated to different temperatures. J Exp Biol 206:2273-2280

Place SP, Zippay ML, Hofmann GE (2004) Constitutive roles for inducible genes: evidence for the alteration in expression of the inducible hsp70 gene in Antarctic notothenioid fishes. Am J Physiol-Regul Integr Comp Physiol 287: R429-436

Rinehart JP, Hayward SA, Elnitsky MA, Sandro LH, Lee RE Jr, Denlinger DL (2006) Continuous up-regulation of heat shock proteins in larvae, but not adults, of a polar insect. Proc Natl Acad Sci U S A 103:14223-14227

Romero-Calvo I, Ocón B, Martínez-Moya P, Suárez MD, Zarzuelo A, Martínez-Augustin O, de Medina FS (2010) Reversible Ponceau staining as a loading control alternative to actin in Western blots. Anal Biochem 401:318-320

Sardella BA, Cooper J, Gonzalez RJ, Brauner CJ (2004) The effect of temperature on juvenile Mozambique tilapia hybrids (Oreochromis mossambicus $\times 0$. urolepis hornorum) exposed to full-strength and hypersaline seawater. Comp Biochem Physiol A-Mol Integr Physiol 137:621-629

Sardella BA, Kültz D, Cech J Jr, Brauner C (2008a) Salinity-dependent changes in $\mathrm{Na}^{+} / \mathrm{K}^{+}$-ATPase content of mitochondria-rich cells contribute to differences in thermal tolerance of Mozambique tilapia. J Comp Physiol B 178:249-256

Sardella BA, Sanmarti E, Kültz D (2008b) The acute temperature tolerance of green sturgeon (Acipenser medirostris) and the effect of environmental salinity. J Exp Zool Part A 309A:477-483

Shen SC, Shao KT, Chen CT, Chen CH, Lee SC, Mok H (1993) Fishes of Taiwan. National Taiwan University, Taipei, Department of Zoology (in Chinese)

Somero GN (2010) The physiology of climate change: how potentials for acclimatization and genetic adaptation will determine 'winners' and 'losers'. J Exp Biol 213:912-920

Tang CH, Lee TH (2013a) Early response of protein quality control in gills is associated with survival of hypertonic shock in Mozambique tilapia. PLOS ONE 8:e63112

Tang CH, Lee TH (2013b) Freshwater acclimation induces stress responses and expression of branchial $\mathrm{Na}^{+} / \mathrm{K}^{+}$-ATPase and proliferating cell nuclear antigen in Takifugu niphobles. J Exp Zool Part A 319:409-421

Tang CH, Wu WY, Tsai SC, Yoshinaga T, Lee TH (2010) Elevated $\mathrm{Na}^{+} / \mathrm{K}^{+}$-ATPase responses and its potential role in triggering ion reabsorption in kidneys for homeostasis of marine euryhaline milkfish (Chanos chanos) when acclimated to hypotonic fresh water. J Comp Physiol B 180:813-824

Tang C-H, Lai D-Y, Lee T-H (2012) Effects of salinity acclimation on $\mathrm{Na}^{+} / \mathrm{K}^{+}-$ ATPase responses and FXYD11 expression in the gills and kidneys of the Japanese eel (Anguilla japonica). Comp Biochem Physiol A-Mol Integr Physiol 163:302-310

Todgham A, Hoaglund E, Hofmann G (2007) Is cold the new hot? Elevated ubiquitin-conjugated protein levels in tissues of Antarctic fish as evidence for cold-denaturation of proteins in vivo. J Comp Physiol B 177:857-866

Wickner S, Maurizi MR, Gottesman S (1999) Posttranslational quality control: folding, refolding, and degrading proteins. Science 286:1888-1893

\section{doi:10.1186/s40555-014-0021-7}

Cite this article as: Tang et al:: Short-term effects of thermal stress on the responses of branchial protein quality control and osmoregulation in a reef-associated fish, Chromis viridis. Zoological Studies 2014 53:21. 